\title{
AN ANALYSIS OF FINNISH SKIING SCHOOL STUDENTS' ACADEMIC EDUCATION AND ATHLETIC SUCCESS
}

\author{
Jan-Erik Romar
}

Faculty of Education, Åbo Akademi University, Vasa, Finland

Submitted in November, 2011

BACKGROUND: Skiing boarding schools provide an opportunity to combine academic education and an athletic career. Many athletes select to go to a boarding school at an age of 16 because they have poor local training possibilities; however, this physical move away from home provides many challenges.

OBJECTIVE: The purpose of this study was to analyze academic education and athletic success of skiing school students in Finland.

METHODS: The participants were 49 students ( 15 girls and 34 boys) with an average age of 17 years. They came from three skiing boarding schools, two cross-country and one alpine school. Sixty percent of the alpine skiers were members of the junior national team while only six percent of the cross-country skiers. All participants completed a survey about study success and athletic performance.

RESULTS: The results showed that $80 \%$ of the students extended their high school studies from three to four years. About $50 \%$ of all students were satisfied with their academic success. Fifty-four percent of alpine skiers and $15 \%$ of cross-country skiers indicated that their best athletic success were in international competitions. Almost all students perceived that skiing school helped by combining sport and school. However, only $40 \%$ of the alpine skiers and $62 \%$ of the cross-country skiers were satisfied with their present athletic success. Seventy-three percent of the alpine skiers felt that sport participation affected negatively their success in school. Success in sport, good training possibilities, skilled coaches and caring friends were reason for enjoying life in skiing boarding schools.

CONCLUSIONS: These findings support the concept of skiing schools and suggest that there are many things to consider when combining education and an athletic career.

Keywords: Talent development, youth education, skiing.

\section{INTRODUCTION}

Student-athlete experiences have been a major concern in many universities and high schools. An area that has generated scholarly interest is the relationship between participation in athletics and academic achievement. Learning to balance academic work and athletics is one of the most obvious challenges that university student-athletes confront (Parham, 1993). They are challenged to find ways of maximizing their involvement and learning in both academic and athletic domains. Because of practice and performance time they may have less time and effort for academics (Peltier \& Laden, 1999).

Another reason that student athletes struggle in college may be that athletes have unrealistic expectations for careers in professional sports (Lucas \& Lovaglia, 2002). If student athletes value their sport as the most viable means to economic success, they may tend to give the most effort, concentration and hope to sport (Beamon \& Bell, 2006). Several studies have shown that athletic motivation and plans to play professionally detracts from academic success (Beamon \& Bell,
2006; Gaston-Gayles, 2004; Lucas \& Lovaglia, 2002). However, Pascarella, Truckenmiller, Nora, Terenzini, Edison, and Hagedorn (1999) reported that the negative cognitive consequences of intercollegiate athletic participation were limited to revenue-producing sports.

In general, academic motivation and academic support programs were important in determining future academic success (Gaston-Gayles, 2004). Coping with athletic success or lack thereof, is a challenge that some student-athletes confront (Parham, 1993). They are also forced to sacrifice the attention paid to their social and leisure needs. In addition, a substantial proportion of athletes see themselves as stigmatized in the academic community. They report they are perceived and treated negatively by the professors, teaching assistants and other students (Simons, Bosworth, Fujita, \& Jensen, 2007).

In addition to these results from universities in United States, Miller and Kerr (2002) reported that Canadian student-athletes experience role conflict and role overload from the dual role. Athletes made a series of negotiations within their academic and social lives. They compromised their social activities as they progressed 
through university and struggled to fulfill their athletic and academic responsibilities. This was particularly true during their early university careers.

In Europe, there are no university athletic scholarships and therefore the structure for student-athletes reflects a different higher education system to that in the United States or Canada. Brettschneider (1999) found in Germany, that top level athletes reported significantly higher general self, peer and parent relations and academic scores. Participation in elite sport may influence the development of young people's self-perceptions in a positive way and that a positive academic self-concept may serve as a personal resource in coping with stress. Many athletes' training schedules are as demanding as their school workload. Adding commuting times, athletes scarcely have two or three hours of free time per day, to be used not only for leisure activities but also for homework. However, they use their free time more economically than the normal adolescent population does. Likewise in the UK, McKenna and Dunstan-Lewis (2004) reported a role conflict that was attributed to student-athletes drastically different expectations, demands, and rewards. Nevertheless, according to student-athletes' achievements, they were successful in both academic and sporting terms.

At the high school level, previous research has generally shown a positive association between students' varsity sports participation and their grades, school progress and college enrollment (Eide \& Ronan, 2001; Fejgin, 1994; Jonker, Elferink-Gemser, \& Visscher, 2009; Zaugg, 1998). Fejgin (1994) also noted a negative effect on discipline problems while Zaugg (1998) found that athletes had fewer behavioral problems and missed significantly fewer classes. Nevertheless, Ryska and Vestal (2004) discussed that the lack of relationship among these variables may reflect that any academic advantage demonstrated by student-athletes represents a precursor to, rather than a result of, sport participation. Sport participation may facilitate students' academic achievement, largely due to the behavioral characteristics developed within that participation.

Ryska and Vestal (2004) reported that the type of motivational goals pursued by high school student- athletes are linked to various adaptive competence perceptions reported within the academics. Also, the type of sport motivation exhibited has a meaningful impact on student-athletes' behavior and attitudes within the academic context. In the Nederlands, Jonker, ElferinkGemser, Toering, Lyons, and Visscher (2010) concluded that the relatively stronger self-regulatory skills reported by the elite youth soccer players may be essential for performance at the highest levels of sport competition and in academia. In addition, Jonker, Elferink-Gemser, and Visscher (2011) found that elite youth athletes have an improved awareness of a task's demands prior to its execution and are more conscious of their previous performance from which they are able to learn.

In Scandinavia, Christensen, and Sørensen (2009) reported how 15 to 19 year old Danish football talents balanced their relationships with culture in the education system and in the football environment. The feeling of time pressure in their everyday lives was the single factor that was the most serious threat to a successful combination of football career and youth education. This could be seen in the choices that have to be made every day about how much they should focus on homework as opposed to football.

The structure for high school student-athletes is similar in Finland and Sweden and there are sport specific high schools for top level young athletes (Metsä-Tokila, 2002). These high schools are either regional or national schools and students are selected based on their academic and athletic performance. There has also been some scholarly interest in this area. Researchers have analyzed grades, grade point averages and academic success for student-athletes and non-student athletes and reported no significant differences (Suomalainen \& Telama, 1988). Many students reported they had to sacrifice their studies because of athletics (Jonsson, 2000; Nummela, 2001). However, results from different studies showed that between $50 \%$ to $75 \%$ of high school student athletes were satisfied with their academic achievements (Nummela, 2001; Suomalainen \& Telama, 1988). In regard to future education plans, at least half of the sport high school students reported that they will consider an education at the university level (Nummela, 2001).

Student-athletes in sport high schools perceived that the school context provided a good place for athletic improvement (Jonsson, 2000; Suomalainen \& Telama, 1988). About half of the sport high school students had been among top three in the Finnish Junior Championships and about $60 \%$ of the students were satisfied with their athletic success (Nummela, 2001). Students wanted to become successful athletes in their sport and they had high goals for their future involvement in sport while most of them wanted to reach an international level (Nummela, 2001).

Combining sports and education without any special arrangements is a demanding task and different educational possibilities have emerged in many countries. There are universal challenges to both university and high school student-athletes in their dual role although most studies are done in the United States. In addition, studies are frequently related to team sports. Therefore, the purpose of this study was to analyze academic performance and athletic success for students in Finnish skiing sport high schools. 


\section{METHODS}

The participants were 49 students ( 15 girls and 34 boys) with an average age of 17 years. Fourteen students were 16 years old, 14 students were 17 years old, 8 students were 18 years old, 7 students were 19 years old and 6 students were 20 years old. They came from three skiing boarding schools, two cross-country (12 girls and 22 boys) and one alpine school ( 4 girls and 11 boys). All participants completed a questionnaire about academic success and athletic performance especially complied for this study. The questionnaire was based on previous studies on sport school students (Nummela, 2001; Sjödin, 2004) and was piloted with former sport school students in Finland. The first part of the questionnaire consisted of four items related to the biography of the student athletes. The next section had three items related to their future educational plans. Students' selfreported absence and training frequency was measured with five items. Academic and athletic performance and perceived success was evaluated with nine Likert scale items. Finally, aspects affecting their satisfaction in the sport school were measured with eleven Likert scale items. Data collection from each school occurred after the competitive season in April. The coaches in each school were informed about the study and they were asked to find an appropriate time when most of the athletes were present in the school. All student athletes that were present completed the questionnaire. In one school data collection was supervised by one of the researchers and in two schools by a school coach.

Descriptive statistics and tests were used to describe the results. A $\chi^{2}$ test was conducted to compare the two sports and an alpha of $p=0.05$ was adopted for test of significance. The analysis was done with regard to the two sports, alpine and cross-country, because of their different culture and demands. Cross-country skiing has in Finland for a long time been a well-known and successful sport while in alpine skiing international success is a new phenomenon. Finland has good facilities for cross-country skiing but lacks high mountains. In addition, a lot more athletes in different ages participate in cross-country than in alpine skiing. However, in this study sixty percent of the alpine students were members of the junior national team while only six percent of the cross-country students. Twenty one students studied their first year, nine were second year students and thirteen were third to fifth year students.

\section{RESULTS}

The presentation of results is divided into three parts; academic work and success, athletics, and the combination of academics and athletics. Most of all high school students (85\%) in Finland graduate in three years, while all alpine students and $79 \%$ of cross-country students indicated that they will graduate in four years. In Finland, a school year consists of 190 work days. When asking the students how many days they were absent from school during the year of study, alpine students were absent in average 88 days while the average for cross-country students was 22 days.

Because students were absent from school, they were expected to do school work during their absences. One third of all students reported that they did school work almost during every training camp when they were away from school (TABLE 1). However, only one alpine student while $42 \%$ of cross-country students reported that they very seldom or never did school work. During road competitions, $60 \%$ of alpine students and $62 \%$ of cross-country students reported that they very seldom or never did school work.

\section{TABLE 1}

Distribution of how frequent students do school work when they are away from school

\begin{tabular}{|l|c|c|c|c|}
\hline \multirow{2}{*}{} & \multicolumn{2}{|c|}{ During training camps } & \multicolumn{2}{c|}{ During road competitions } \\
\cline { 2 - 5 } & $\begin{array}{c}\text { Alpine } \\
\%\end{array}$ & $\begin{array}{c}\text { Cross-country } \\
\%\end{array}$ & $\begin{array}{c}\text { Alpine } \\
\%\end{array}$ & $\begin{array}{c}\text { Cross-country } \\
\%\end{array}$ \\
\hline Every time & 0 & 3 & 0 & 3 \\
\hline $\begin{array}{l}\text { Almost } \\
\text { every time }\end{array}$ & 33 & 33 & 20 & 12 \\
\hline $\begin{array}{l}\text { Rather } \\
\text { seldom }\end{array}$ & 60 & 21 & 20 & 33 \\
\hline $\begin{array}{l}\text { Very } \\
\text { seldom }\end{array}$ & 7 & 30 & 60 & 23 \\
\hline Never & 0 & 12 & 0 & 29 \\
\hline \multicolumn{2}{|c|}{$\chi^{2}(4, \mathrm{~N}=49)=9.44, \mathrm{p}=.051$} & $\chi^{2}(4, \mathrm{~N}=49)=11.9, \mathrm{p}=<.05$ \\
\hline
\end{tabular}

Nevertheless, about half of all students were very satisfied or satisfied with their academic success. One third could not say and $12 \%$ were dissatisfied with their academic success. Immediately after graduation, about half of all students planned to apply to a university. Twenty-two boys planned to do their army service. However, there were less alpine students going to university, because they intended to do other things, such as going abroad, working or staying at home. The long term educational plan was for $80 \%$ of all students to study at university or polytechnic level. Only two students' future educational goals were to become professional athletes.

Fifty-four percent of alpine skiers and $15 \%$ of crosscountry skiers indicated that their best athletic success were in international competitions, like Junior World Championships or Junior Nordic Championships. Sixty-five percent of cross-country students indicated that their best athletic success were from National Championships. However, only $40 \%$ of the alpine students 
and $62 \%$ of the cross-country students were satisfied or very satisfied with their present athletic success. Students spend much time in practice and competitions and during the training season at their local school all students trained in average nine to ten times per week. At trainings camps, alpine students trained eleven times and cross-country students thirteen times per week.

Students' athletic goals for the following season were for alpine students mostly related to international competitions while cross-country students' goals were related to success in national championships. The most frequent long term athletic goals for all students were to reach to national team, to get an Olympic medal, or to become a professional athlete (TABLE 2).

Almost all students (alpine $=87 \%$ and cross-country $=97 \%$ ) perceived that skiing school helped much or very much by combining academic and athletics. Although, when specifically asking about the effect of

\section{TABLE 2}

Students' long term athletic goal

\begin{tabular}{|l|c|c|}
\hline & $\begin{array}{c}\text { Alpine } \\
\%\end{array}$ & $\begin{array}{c}\text { Cross-country } \\
\%\end{array}$ \\
\hline Medal in National Championships & 7 & 21 \\
\hline National team & 27 & 32 \\
\hline Medal in World Championships & 0 & 9 \\
\hline Olympic medal & 20 & 23 \\
\hline Professional career & 20 & 12 \\
\hline Other (best in the world, nothing) & 26 & 3 \\
\hline \multicolumn{2}{|c|}{$\chi^{2}(5, \mathrm{~N}=49)=9.0$, n. s. }
\end{tabular}

athletics on their academic performance, $73 \%$ of the alpine students and $15 \%$ of cross-country students felt that athletic participation negatively affected their success in school (TABLE 3). Looking at the combination of academics and athletics from another perspective, half of the alpine students and $27 \%$ of cross-country students perceived that academic work somewhat diminished their possibilities to reach their athletic goals.

Students were asked to react to aspects affecting their satisfaction in the sport high school (Fig. 1). Students emphasized aspects related to athletic work. Athletic success, good training possibilities, skilled coaches and caring friends were the most important factors for enjoying life in schools. Alpine students scored significantly higher on athletic success while cross-country students scored significantly higher on combination of academics and athletics, health care services, good teachers and interesting courses.

\section{TABLE 3}

Students' perceptions of how athletics affected their academic work

\begin{tabular}{|l|c|c|}
\hline & $\begin{array}{c}\text { Alpine } \\
\%\end{array}$ & $\begin{array}{c}\text { Cross-country } \\
\%\end{array}$ \\
\hline Very helping & 0 & 0 \\
\hline Helping & 7 & 44 \\
\hline No affect & 20 & 41 \\
\hline Detrimental & 73 & 15 \\
\hline Very detrimental & 0 & 0 \\
\hline \multicolumn{2}{|c|}{$\chi^{2}(2, \mathrm{~N}=49)=16.7, \mathrm{p}<.001$}
\end{tabular}

Fig. 1

Aspects affecting students' satisfaction of the sport high school

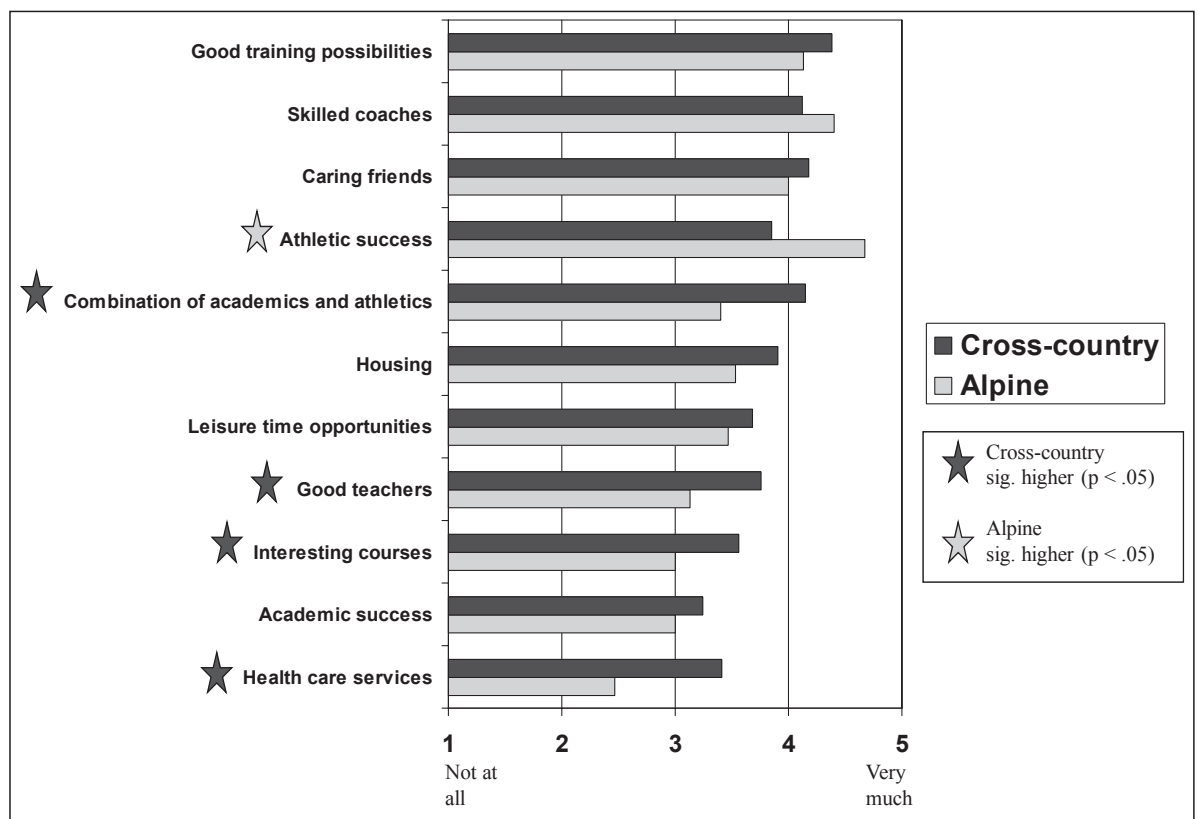




\section{DISCUSSION}

These findings support the concept of skiing schools and show that there are many things to consider when combining education and a beginning athletic career. As in previous research (Metsä-Tokila, 2002; Nummela, 2001), most of the skiing students extended their time in high school to four years, which is reasonable due to the frequent absences. Alpine students were absent almost half of the school year because of training and competition but similarly, alpine students did school work more frequently during training camps. However, almost two thirds of all students did hardly any school work during competitions, which shows that their focus was mostly directed towards competing. Also Beamon and Bell (2006) concluded that student athletes tend to give most effort, focus and hope to sport. In addition, when these student athletes were at school, they practiced in average ten times a week which with all included is at least 20 to 25 hours of work per week. A demanding situation is obvious and students have to cope with stress and to negotiate their social and leisure needs (Brettschneider, 1999; Christensen \& Sørensen, 2009).

Although they miss a great deal of school work, the skiing students were satisfied with their academic education and showed an interest in future university studies. One could expect they will graduate from high school, because previous studies have shown no significant differences in academic success for student-athletes and non-student athletes (Leivo, 1999; Suomalainen \& Telama, 1988). These student-athletes have not rejected the importance of education and can see themselves studying for a real job, not just having unrealistic expectations for professional sports careers (Lucas \& Lovaglia, 2002). When student athletes live their lives like they have chosen to do, this will foster independent study and self-regulatory skills while working towards a clear goal (Jonker et al., 2010; Ryska \& Vestal, 2004). As Jonsson (2000) stated, the benefits are perhaps not always purposeful and well planned but will enhance socialization into adulthood with its norms, values and habits.

The goals for sport high schools are to provide high level training, competent coaches and good training possibilities. The ski federation is involved in the selection process, which will provide these schools with talented athletes. The result showed that the skiing students were successful athletes, which is supported in previous research in Finland (Metsä-Tokila, 2002; Nummela, 2001). To have an international success in a specific event was a goal for half of all students. The alpine students were more successful in athletics but they were still critical and not always satisfied with their athletic success. All these student-athletes put much time and effort into their athletic career and they can see the benefits of going to a boarding skiing school. They know that at home it would be difficult to have the same sport commitment and emphasis on academic study. However, with high athletic aspirations they were not satisfied with the present situation. The dual role (Miller \& Kerr, 2002) was demanding with school requirements on one hand and the dream of success on the snow on the other.

Finally, what stands out is that the number one focus for these students-athletes is to achieve a high level of success in their athletic performance, which GastonGayles (2004) also reported. This finding is represented in the aspects affecting satisfaction in school. All students valued things that helped them pursue an athletic career. The athletic emphasis was more evident for alpine students than for cross-country students, who valued significantly higher aspects related to academic performance.

There are several limitations to this study. First, a self-report questionnaire was used which could be susceptible to socially desirable answers. Another shortcoming of our study relates to the culture where the study was done. These results reflect the athletic and academic situation only for individual winter athletes in Finland although there are some universal issues related to all student athletes.

\section{CONCLUSION}

The study has confirmed that the student-athlete is well nurtured and served at high school level and many students have clear goals for their future education. Our findings have some preliminary implications for the coaches and school faculty members directly or indirectly involved with young athletes. Encouraging student athletes to apply their self-regulatory skills inside and outside their sports may help them to balance their athletic and academic life in a better way and also support their education. As a part of this, the sport high school should attract former top level athletes to work with the student athletes as mentors. These mentors could share their own experiences from an educational and an academic perspective.

\section{REFERENCES}

Beamon, K., \& Bell, P. A. (2006). Academics versus athletics: An examination of the effects of background and socialization on African, American male student athletes. The Social Science Journal, 43, 393-403.

Brettschneider, W. D. (1999). Risks and opportunities: Adolescents in top level sport: Growing up with the pressures of school and training. European Physical Education Review, 5(2), 121-133. 
Christensen, M. K., \& Sørensen, J. K. (2009). Sport or school? Dreams and dilemmas for talented young Danish football players. European Physical Education Review, 15(1), 115-133.

Eide, E. R., \& Ronan, N. (2001). Is participation in high school athletics an investment or a consumption good? Evidence from high school and beyond. Economics of Education Review, 20, 431-442.

Fejgin, N. (1994). Participation in high school competitive sport: A subversion of school mission or contribution to academic goals? Sociology of Sport Journal, 11(3), 211-230.

Gaston-Gayles, J. L. (2004). Examining academic and athletic motivation among student athletes at a division I university. Journal of College Student Development, 45(1), 75-83.

Jonker, L., Elferink-Gemser, M. T., Toering, T. T., Lyons, J., \& Visscher, C. (2010). Academic performance and self-regulatory skills in elite youth soccer players. Journal of Sports Sciences, 28(14), 1605-1614.

Jonker, L., Elferink-Gemser, M. T., \& Visscher, C. (2009). Talented athletes and academic achievements: A comparison over 14 years. High Ability Studies, 22, 55-64.

Jonker, L., Elferink-Gemser, M. T., \& Visscher, C. (2011). The role of self-regulatory skills in sport and academic performances of elite youth athletes. Talent Development \& Excellence, 3(2), 263-276.

Jonsson, R. (2000). Kroppen eller knoppen en ESO rapport om idrottsgymnasierna. Stockholm: Government Offices of Sweden.

Lucas, J. W., \& Lovaglia, M. J. (2002). Athletes' expectations for success in athletics compared to academic competition. The Sport Journal, 5(2). Retrieved 2. 11. 2011 from the World Wide Web: http://www. thesportjournal.org/tags/volume-5-number-2

McKenna, J., \& Dunstan-Lewis, N. (2004). An action research approach to supporting elite student-athletes in higher education. European Physical Education Review, 10(2), 179-198.

Miller, P. S., \& Kerr, G. (2002) The athletic, academic and social experiences of intercollegiate student- athletes. Journal of Sport Behavior, 25(4), 346-371.

Metsä-Tokila, T. (2002). Combining competitive sports and education: How top level sport became part of the school system in the Soviet Union, Sweden and Finland. European Physical Education Review, 8(3), 196-206.

Nummela, N. (2001). Kilpaurheilu elämän keskipisteessä: Urheilulukiolaisten kilpaurheilullinen elämäntapa [Competitive sport as the center of life: Sport high school students way of life]. Unpublished master's thesis, University of Oulu, Faculty of Education, Oulu.

Parham, W. D. (1993). The intercollegiate athlete. The Counseling Psychologist, 21(3), 411-429.
Pascarella, E. T., Truckenmiller, R., Nora, A., Terenzini, P. T., Edison, M., \& Hagedorn, L. S. (1999). Cognitive impacts of intercollegiate athletic participation. The Journal of Higher Education, 70(1), 1-26.

Peltier, G. L., \& Laden, R. (1999). Do high school athletes succeed in college? A review of research. High School Journal, 82(4), 234-238.

Ryska, T. A., \& Vestal, S. (2004). Effects of sport motivation on academic strategies and attitudes among high school student-athletes. North American Journal of Psychology, 6(1), 101-120.

Simons, H. D., Bosworth, C., Fujita, S., \& Jensen, M. (2007). The athlete stigma in higher education. College Student Journal, 41(2), 251-273.

Sjödin, T. (2004). Förståelse av kommunikation mellan alpina skidåkare och deras tränare [The understanding of communication between alpine skiers and their coaches]. Unpublished study, University of Göteborg, Faculty of Education, Gothenburg.

Suomalainen, M., \& Telama, R. (1988). Urheilijan koulutustutkimus: lähtötilanteen selvitys [Athletes and education: A baseline report]. Liikunta ja tiede, 25(5), 236-241.

Zaugg, H. (1998). Academic comparison of athletes and non-athletes in a rural high school. NASSP Bulletin, $82,63-72$.

\section{ANALÝZA AKADEMICKÉHO VZDĚLÁNÍ A SPOR- TOVNÍCH ÚSPĚCHŮ STUDENTU゚ FINSKÝCH LYŽAŘSKÝCH ŠKOL}

(Souhrn anglického textu)

VÝCHODISKA: Lyžařské internátní školy nabízejí možnost spojit akademické vzdělání a sportovní kariéru. Mnozí sportovci odcházejí ve věku 16 let na internátní školu, jelikož v místě svého bydliště mají špatné tréninkové podmínky; toto odloučení od domova však přináší množství problémů.

CÍL: Cílem této studie byla analýza akademického vzdělání a sportovních úspěchů studentů lyžařských škol ve Finsku.

METODY: Výzkumu se zúčastnilo 49 studentů (15 dívek a 34 chlapců) průměrného věku 17 let. Jednalo se o studenty tř́i lyžařských internátních škol, z nichž dvě byly zaměřené na běh na lyžích a jedna na alpské lyžování. Členy juniorského reprezentačního týmu bylo šedesát procent sjezdových lyžařŭ, avšak jen šest procent běžců na lyžích. Všichni účastníci vyplnili dotazník o studijních úspěších a sportovních výkonech.

VÝSLEDKY: Výsledky ukázaly, že $80 \%$ studentů si prodloužilo středoškolské studium ze tř́i na čtyři roky. Studenti byli přibližně z 50 \% spokojeni se svými akademickými úspěchy. Padesát čtyři procent sjezdových lyžařů a 15 \% běžců na lyžích uvedlo, že největších 
sportovních úspěchů dosáhli v mezinárodních soutěžích. Téměř všichni studenti naznačili, že lyžařská škola jim pomohla zkombinovat sport a vzdělání. Ovšem pouze $40 \%$ sjezdových lyžařů a $62 \%$ běžců na lyžích bylo spokojeno se svými současnými sportovními úspěchy. Sedmdesát tři procent sjezdových lyžařủ cítilo, že sportovní aktivity měly negativní vliv na jejich výsledky ve škole. Spokojenost se životem na lyžařských internátních školách byla podpořena sportovními úspěchy, dobrými tréninkovými možnostmi, kvalifikovanými trenéry a pozornými přáteli.

ZÁVĚRY: Tyto výsledky podporují koncepci lyžařských škol a vyplývá z nich, že při spojení akademického vzdělání a sportovní kariéry je třeba zvážit mnoho věcí.

Klíčová slova: rozvoj talentu, vzdělávání mládeže, lyžování.

\section{Jan-Erik Romar, Ph.D.}

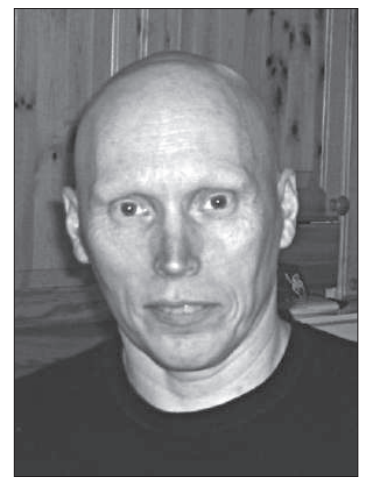

Åbo Akademi University

Box 311

65101 Vasa

Finland

\section{Education and previous work experience}

2009 - Docent in Sport Pedagogy at Åbo Akademi University.

1994 - Degree of Doctor of Philosophy at the Ohio State University.

1984 - Master's Degree in Physical Education, University of Jyväskylä.

Since 1984 - lecturer in sport pedagogy at the Faculty of Education at Åbo Akademi University.

1991-1993 - graduate teaching assistant at the Ohio State University.

\section{First-line publication}

Romar, J.-E. (1994). Adolescent athletes' perceived sport competence and motives for individual sports. The Physical Educator, 51(3), 114-118.

Tannehill, D., Romar, J.-E., O’Sullivan, M., England, K., \& Rosenberg, D. (1994). Attitudes towards physical education: Their impact on how physical education teachers make sense of their work. Journal of Teaching in Physical Education, 13(4), 407-421.

Romar, J.-E., \& Siedentop, D. (1995). Cooperation and body control as goals in physical education: A case study of a basketball unit. In C. Pare (Ed.), Proceedings from AIESEP International Seminar: The training of teachers in reflective practice of physical education. Better teaching in physical education? Think about it! (pp. 205-222). Canada: Trois-Rivières.

Romar, J.-E. (2000). Preservice teachers' understanding of teaching physical education. In F. Carreiro da Costa, J. A. Diniz, L. M. Carvalho, \& M. S. Onofre (Eds.), Proceedings of the AIESEP 96 International Seminar: Research on teaching and research on teacher education (pp. 239-244). Portugal: Lisbon.

Romar, J.-E., Mattbäck, T., \& Strömvall, S.-M. (2007). Socialisation into soccer. In P. Heikinaro-Johansson, R. Telama, \& E. McEvoy (Eds.), The role of physical education in promoting physical activity and health (pp. 276-283). University of Jyväskylä: Department of Sport Sciences Research.

Williams, E., Romar, J.-E., \& Hartman, M. (2010) British and Finnish baseball: International variations on an American pastime. Strategies, 23(3), 24-27.

Romar, J.-E., \& Pettersson, E. (2011). Professional development for physical educators through active learning with friends. In J. A. Sánchez Molina, O. Carballo, \& M. A. González Valeiro, (Eds.), Actas del Congreso Internacional de la AIESEP (2010) (pp. 1574-1583). Alicante: Editorial Alto Rendimiento.

Romar, J.-E., Fagerström, E., \& Granlund, E. (2011). Students' experiences of using heart rate monitors during physical education lessons. In A. MacPhail \& M. O'Sullivan (Eds.), Proceedings of AIESEP International Conference (pp. 525-554). Limerick: University of Limerick. 